jolantatambor@yahoo.ca

\title{
Stylizacja - pomysł na reaktywację śląszczyzny
}

AвSTRACt: Tambor Jolanta, Stylizacja - pomyst na reaktywację śląszczyzny (Stylization - Ideas for the Reactivation of the Silesian Language). „Poznańskie Studia Slawistyczne” 8. Poznań 2015. Publishing House of the Poznań Society for the Advancement of the Arts and Sciences, pp. 215228. ISSN 2084-3011.

In the article, the status of the Silesian ethnolanguage is shortly discussed. The opinions of two groups writing about this topic are presented: those writing from the perspective of the detailed linguistics (historical) and those writing from the perspective of the general linguistics. The author mentions also about the social, legal, and political background that creates the status of ethnolanguages in the contemporary political-legal situation of Europe. Basing on these, the author analyzes publications of the recent 25 years, which belong to popular scientific writings and belles-lettres. She exposes their role in raising of the prestige of the Silesian ethnolanguage.

KeYwords: Silesia; Silesian ethnolanguage; codification; literary language

O sytuacji etnolektu śląskiego napisano w ostatnich latach bardzo wiele. Pojawiło się mnóstwo artykułów naukowych, liczne wystąpienia konferencyjne, co pewien czas temat wraca w debatach publicystycznych, staje się przedmiotem obrad sejmowej Komisji ds. Mniejszości Narodowych i Etnicznych. Dyskusje te - jak się wydaje - utknęły w martwym punkcie. Wyklarowały się dwa rozbieżne stanowiska.

Opcja językoznawczo-gramatyczna, czy może raczej historycznojęzykowa, odnosi się do wewnątrzjęzykowych uwarunkowań mowy i jej odmian. Zwolennicy tej koncepcji posługują się tradycyjnymi, w zasadzie wyłącznie systemowymi, narzędziami do odróżniania języków od ich odmian terytorialnych, którymi są dialekty (pojęcie gwar jest już rzadziej używane). Możliwość uznania niektórych etnolektów regionalnych za dialekty języków narodowych jest przede wszystkim argumentowana wzajemną ich zrozumiałością, liczbą identycznych struktur lub wspólną 
przeszłością. Koncepcja wzajemnej zrozumiałości jest dziś w zasadzie nie do utrzymania - tym bardziej że jest trudna do zmierzenia, zależna od tzw. talentu językowego, słuchu językowego czy wreszcie, choćby biernej, znajomości różnych języków. Niektórzy Polacy twierdzą, że bez problemu rozumieją mówiących po słowacku i z nieco większą trudnością mówiących po czesku, inni natomiast zupełnie nie rozumieją wypowiedzi naszych południowych sąsiadów. Trzeba by przeprowadzać zakrojone na szeroką skalę badania, by móc ocenić stopień zrozumienia języków (etnolektów) przez użytkowników, jednakże trudno wyobrazić sobie takie badania. Niekoniecznie też uspokoiłyby one spory, skoro za języki uznano etnolekty o prawie stuprocentowej wzajemnej zrozumiałości, jak choćby serbski i chorwacki. Kolejny argument wypływa z poprzedniego: tożsamość słownictwa i struktur gramatycznych (składniowych, morfologicznych) w dwu etnolektach i został obalony ćwierć wieku temu przez Alfreda Majewicza, który pisał, że

niemożność ustalenia liczby języków świata wynika m.in. z niemożności ustalenia precyzyjnego kryterium, precyzyjnej miarki pozwalającej bez żadnych wątpliwości odróżnić etnolekt ze statusem odrębnego języka od etnolektu ze statusem dialektu typu, np. ,jeżeli dwa etnolekty mają 80\% wspólnego słownictwa, 98\% wspólnych struktur syntaktycznych itp. i jeden z nich musi być uważany za podrzędny w stosunku do drugiego, ponieważ... (tu uzasadniamy), to wtedy ten pierwszy stanowi dialekt tego drugiego, a nie po prostu język jemu pokrewny" (rozumie się przez to, że np. $79 \%$ wspólnego słownictwa i 96\% wspólnych struktur syntaktycznych itp., czy brak możliwości uzasadnienia stosunku podrzędności takie ustalenie by wykluczało). Ustalenie takich kryteriów jest niemożliwe, gdyż każda cecha charakterystyczna dla danego języka, podstawowe słownictwo włączając, może wystąpić w jakimkolwiek innym języku bardzo daleko spokrewnionym lub niepokrewnym w ogóle. (...) Z językoznawczego punktu widzenia jednakowo uprawnione jest sklasyfikowanie np. wszelkich odmian niemieckiego, holenderskiego i afrikaansa jako dialektów jednego języka, jak i przyznanie statusu odrębnych języków (...) afrikaansowi, holenderskiemu i flamandzkiemu, ale nawet niemieckiemu szwajcarskiemu, luksemburskiemu, niemieckiemu austriackiemu (Majewicz 1989: 12-13).

Ten cytat, wielokrotnie już przytaczany, pozostaje aktualny. Najtrudniejszy do dyskusji, bo mocno zideologizowany, jest argument o wspólnej przeszłości. Należy przytoczyć w tym miejscu słowa Jana Miodka, który przypomniał wypowiedź Aleksandra Brücknera o śląskim jako skarbnicy staropolskiej, co jakoby implikowało stwierdzenie, że śląski jest najbardziej polskim z polskich dialektów. Nie trzeba się przecież odcinać od 
polskości jako jednej z odmian słowiańszczyzny, by prezentować stanowisko „niedialektalne”. Etnolekt śląski rozwijał się w bezpośrednim kontakcie z kształtującym się narodowym etnolektem, czyli językiem polskim, ale też przez wiele lat i na sporym obszarze czeskim. Nie da się nie zauważyć ścisłych jego kontaktów z językiem niemieckim, który pozostawił w tym niewątpliwie słowiańskim ciele sporo śladów w słownictwie i zdecydowanie mniej w strukturach gramatycznych - choć są one dość charakterystyczne. Ideologizacja problemu powoduje zresztą w niektórych środowiskach, dążących do specyficznej rewitalizacji śląszczyzny, nadmierny zwrot w kierunku germanizmów ${ }^{1}$, włącznie $z$ tworzeniem neologizmów na bazie języka niemieckiego (jak cwajmonatszrift - na oznaczenie dwumiesięcznika).

Druga grupa piszących o statusie śląszczyzny odwołuje się do czynników społeczno-politycznych związanych z uchwaleniem i ratyfikowaniem przez Polskę Europejskiej karty języków regionalnych lub mniejszościowych oraz zatwierdzeniem polskiej Ustawy z dnia 6 stycznia 2005 r. o mniejszościach narodowych i etnicznych oraz o języku regionalnym. W świetle tych dokumentów pojęcie języka regionalnego (pomocniczego) jawi się jako pojęcie prawno-polityczne, do którego nie mają w zasadzie zastosowania narzędzia systemowe. Dyskusję na temat statusu śląszczyzny z uwzględnieniem nowych kryteriów i warunków społeczno-prawno-politycznych, w jakich przyszło tę kwestię rozważać, rozpoczął Władysław Lubaś tekstem Czy powstanie śląski język literacki?, zamieszczonym w „Języku Polskim” w 1998 roku (Lubaś 1998: 49-56). Autor powoływał się wielokrotnie w różnych miejscach, także i w tym artykule, na słowa wybitnego językoznawcy Kazimierza Polańskiego, który w wywiadzie dla miesięcznika „Śląsk” (1997, nr 6) powiedział:

problem odróżniania języków od gwar nie jest problemem czysto lingwistycznym, to problem raczej socjologiczny, psychologiczny. W pewnej mierze też polityczny. Nie da się ustalić kryteriów językoznawczych, które by pozwalały odróżnić język od gwary. Zasadniczą sprawą jest tu świadomość językowa, która powoduje, że pewna wspólnota językowa w określonym momencie dojrzewa i decyduje się na usamodzielnienie:

${ }^{1}$ Chodzi mi tu o tworzenie nowych, sztucznych terminów, wyrazów. Zrozumieć należy i ocenić jako właściwe w procesie reaktywacji (rewitalizacji) przywoływanie tych, które w ostatnich (kilkudziesięciu) latach wycofały się ze słownictwa czynnego sporej liczby użytkowników śląszczyzny. 
opracowuje słownik swojego języka, dokonuje kodyfikacji reguł jego użycia, reguł pisowni, wyboru alfabetu itd. Od tej chwili można mówić o odrębnym języku (za: Lubaś 1998: 56).

Należałoby uznać, że te warunki zostały spełnione: nie ma śląskiego języka standardowego, literackiego, w pełni skodyfikowanego. Warto byłoby się jednak także zastanowić, czy jest on potrzebny i pożądany przez śląską ,wspólnotę językową”. Można uznać, że proces opracowywania słownika jest zakończony. Istnieje spora liczba słowników śląsko-polskich i polsko-śląskich popularnych, amatorskich (podaję przykłady w bibliografii): ich obfitość świadczy o silnej potrzebie społecznej takich opracowań, skłaniającej do działania pasjonatów wobec braku inicjatywy naukowców, językoznawców. Trwa wydawanie (wraz z digitalizacją) naukowego Stownika gwar ślaskich pod red. Bogusława Wyderki (2000 i n.), mamy Słownik etymologiczny nazw geograficznych Ślaska pod red. Stanisławy Sochackiej, opracowania doczekała się śląska frazeologia w postaci obszernego Stownika frazeologizmów i typowych połaczeń wyrazowych w gwarach ślaskich Lidii Przymuszały (2013). Bardzo zaawansowany jest proces kodyfikacji pisowni z wyborem alfabetu włącznie. Czy nie czas zatem na zmianę stanowiska? Władysław Lubaś pisze, że ,główna rola języka śląskiego skupi się na funkcji symboliczno-identyfikacyjnej" (Lubaś 2013: 345). Podobnie rolę śląskiego pokazuje B. Wyderka, który w wystąpieniu na V Kongresie Polonistyki Zagranicznej użył dla takich etnolektów określenia ,język kulturowy”. W wypowiedziach obu językoznawców pobrzmiewa jedna kwestia, którą uważamy za najistotniejszą dla całej sprawy. Śląski język regionalny, pomocniczy język regionalny, nieaspirujący do pozycji języka narodowego (a tym bardziej państwowego), nie musi wykazywać pełnej poliwalencyjności. Nie ma powodu dążyć do zbudowania sztucznego tworu, który miałby wyprzeć faktycznie używane postacie etnolektu śląskiego, nie warto ujednolicać trzech głównych odmian terytorialnych (północnej, środkowej i południowej) etnolektu. Bezcelowe jest wytwarzanie terminologii naukowej, technicznej (dotyczącej nowych technologii), z dziedziny humanistycznej itd. tylko po to, by poszerzyć krąg tekstów, w których byłby użyty etnolekt śląski.

Można scharakteryzować na różnych przykładach drogę od uznania statusu języka (regionalnego, mniejszościowego) do wytworzenia wersji standardu literackiego. Początek tej drogi wytyczają podstawowe akty 
kodyfikacji - jak te wymienione wcześniej dla śląskiego, potem muszą nastąpić dalsze prace nad porządkowaniem norm kolejnych podsystemów etnolektu. Obecny stan łemkowszczyzny tak opisuje jej największy znawca i kodyfikator Henryk Fontański:

Język Łemków - grupy etnicznej górali karpackich, do roku 1947 w zwartej populacji zamieszkujących obszar w Beskidzie Niskim zwany Łemkowszczyzną, a obecnie po wysiedleniu, rozproszonej w różnych regionach Polski i poza jej granicami - od wielu lat jest przedmiotem zainteresowania lingwistów. Do niedawna mowa Łemków opisywana była - a przez niektórych językoznawców także obecnie jest tak traktowana - jako zespół dialektów języka ukraińskiego. Proces unifikacji, standaryzacji i kodyfikacji języka łemkowskiego ma już trwającą wiele dziesięcioleci historię. Dobrze opisane zostały: fonetyka i fonologia, słownictwo i nazewnictwo łemkowskie, historia języka, ale na uzupełnienie i pogłębienie czeka opis gramatyczny (Fontański 2014: 7 [podkr. J.T.]).

Dość podobnie brzmi syntetyczny opis Fontańskiego do tego, co wskazaliśmy dla stanu śląszczyzny. Oba fenomeny językowe różni jeden czynnik: ustawodawstwo polskie nie uznało dotąd śląszczyzny za język. Dalsza lektura tekstu Studiów nad składnia łemkowska pozwala wskazać jeszcze jedną różnicę: autor pisze, że łemkowszczyzna jest używana w prozie, poezji, dramaturgii, publicystyce czy tekstach naukowych (cf. Fontański 2014: 7). Nie ma dotąd (nie wiadomo, czy będą i czy chcielibyśmy, by były) tekstów naukowych po śląsku. Jest to jednak różnica, jak gdyby wpisana w status obu etnolektów: łemkowski uzyskał w ustawie rangę języka mniejszości etnicznej, bliższą językowi mniejszości narodowej (opartej na - niemal - równoważności z językiem narodowym używanym przez naród zorganizowany we własnym państwie, do którego się odnosi). Mniejszości etniczne wymienione w polskiej ustawie (łemkowski, karaimski, tatarski, romski) mają swoje centrum poza granicami Polski ${ }^{2}$ w przypadku zaś śląszczyzny mówimy o statusie języka regionalnego, języka grupy, której centrum (zarówno dla kaszubskiego, jak i śląskiego) istnieje w granicach państwa polskiego i jest z nią nierozerwalnie związane (nie odnoszę się tu do uwarunkowań politycznych w historii).

Spójrzmy więc, gdzie i w jaki sposób pojawia się dziś pisana śląszczyzna. Czy teksty po śląsku, znajdujące się na półkach księgarskich, na

${ }^{2}$ Warto tu dodać, że łemkowski, w polskim ustawodawstwie uznany za język mniejszościowy, w prawie ukraińskim uznawany jest (podobnie jak rusiński) za dialekt ukraiński. 
deskach teatralnych, w ekspozycjach (popularno)naukowych można uznać za kolejny - ważny w świetle ocen językoznawczych - krok na drodze do ujęzykowienia?

Zacznijmy od kwestii (popularno)naukowych. Zapanowała moda na używanie śląskiego w różnorakich sytuacjach: po śląsku mówili do kursantów instruktorzy w telewizyjnym programie Nauka jazdy, jedna z firm oferujących GPS, NaviExpert, wykorzystała głos śląskiego aktora i kabareciarza Grzegorza Stasiaka, który ubarwił działanie urządzenia komendami w rodzaju: „Kaj Ty jedziesz, pieronie” czy „Jadymy, Ty zakamuflowano opcjo niemiecko". Należy nadmienić, że w takiej wersji ów nawigator jest raczej umilającym znaną trasę kabaretem drogówkowym niż faktycznym pomocnikiem w dotarciu na miejsce. Ekspozycje po śląsku albo prawie po śląsku postanowiło pokazać Muzeum Śląskie, które już niedługo otworzy wystawy podziemne w nowej siedzibie na terenie dawnej Kopalni Węgla Kamiennego „Katowice” oraz Muzeum Powstań Śląskich w Świętochłowicach. Obie placówki muzealne postanowiły umieścić kwestie śląskie wyłącznie w wersji mówionej, co należy uznać za fortunną decyzję, ponieważ pomimo starań różnych osób i stowarzyszeń o standaryzację pisowni śląskiej (wśród nich trzeba wyróżnić Tôwarzistwo Piastowaniô Ślónskij Môwy „Danga”, „Pro Loquela Silesiana” Towarzystwo Kultywowania i Promowania Śląskiej Mowy oraz Przymierze Śląskie), nie ma społecznej zgodności co do przyjętego systemu zapisu, brak instytucji czy autorytetów, zdolnych przeforsować wypracowany system; obecnie nie toczą się żadne prace $\mathrm{w}$ tej dziedzinie. Wersja mówiona zapewne jest do zaakceptowania przez większość: pisana mogłaby wzbudzić o wiele większe kontrowersje.

Zastrzegam, że wersja mówiona (w ekspozycjach muzealnych) ma szansę na sporą akceptację społeczną: sporą, ale nie całkowitą, co do tego nie mam złudzeń. Wobec braku wypracowanego tzw. standardu literackiego śląszczyzny, do głosu dojdą zapewne różnice terytorialne. Nawet jeśli odwiedzający ekspozycję zaakceptują użycie wersji ,środkowośląskiej”, czyli wariantu Górnego Śląska przemysłowego, katowickiego, bytomsko-gliwickiego (co do nazw obszarów wewnętrznego podziału nie ma również pełnej zgody), zapewne będą mieli różnorakie zastrzeżenia co do wygłaszanych kwestii, wynikające z:

1) drobnych różnic występujących w mowie nawet na obszarach od siebie nieodległych: rybnickie yny wobec bliżej katowickiego ino/ 
yno, rybnickiego $n i$ wobec katowickiego niy, różnic osobniczych: fyrlok, kfyrlok; Kochłowice, Kochlowice, niuansów mazurzenia zleksykalizowanego (w ekspozycji z mazurzenia zrezygnowano całkowicie);

2) charakteru tekstów wypowiadanych po śląsku.

Na ten drugi aspekt chciałabym zwrócić większą uwagę. Otóż - jak już wcześniej wspomniałam - kodyfikacja czy standaryzacja dotyczy obecnie na Górnym Śląsku przede wszystkim pisowni, dość dobrze jest opracowane słownictwo i morfologia, ale to, co wpływa równie silnie na odbiór tekstów, a jest zdecydowanie mniej uchwytne, to składnia i najogólniej rozumiany styl wypowiedzi. Łemkowszczyzna (o wiekowej tradycji) doczekała się dobrego opracowania składni dopiero w tym roku, co każe sądzić, że na śląską przyjdzie jeszcze poczekać. Poza tym - jak już pisałam - śląszczyzna nie ma i nie wiadomo, czy kiedykolwiek mieć będzie odmianę naukową lub choćby popularnonaukową, trudno bowiem powiedzieć, czy jest ona konieczna. Jak wiadomo z opisów ustandaryzowanych języków narodowych, oficjalnych, właśnie poziom wyższej organizacji tekstu (obok - rzecz jasna - terminologii) jest cechą najwyraźniej odróżniającą teksty naukowe. Prace z różnych dziedzin nauki, które próbuje się przerabiać na śląski, opierają się najczęściej na układzie składniowym wziętym wprost z naukowej polszczyzny ogólnej i w związku z tym „nie brzmią" po śląsku, w skrajnych przypadkach mają wydźwięk wręcz parodystyczny. Autorzy bardzo się starają, trzeba jednak przyznać, że brak pełnego zestawu reguł, ale też nieznajomość tych, które już udało się ustalić, powoduje, iż niektóre teksty, pod wieloma względami akceptowalne, zawierają elementy, które psują cały efekt. Poniżej przytaczam hasło, w którym widać specyficznie oznaczaną miękkość i zmiękczenie oraz brak rozeznania co do miejsc pojawiania się $a$ pochylonego:

Yaku we japōńskim mahjongu (jap.: 役) - prawidła we japōńskim mahjongu ze kerych rychtōje siye punkty. Znajōmość yaku je ważnŏ do strategiji, atoli niy je ôbowiōnskowŏ. Szpiler musiy miyeć jednŏ yaku we rynce coby legalniye wygrŏć rundã. Kŏżde yaku mŏ szpecjŏlny wert han. Regle Yaku mŏgōm być tak zônaczone coby zbajstlowóć jeszcze lepszo rynkã. Szpil mo tyż dora, kerŏ dodowo rynce wert han, atoli niy je to zaliczanŏ kej yaku (<http://szl.wikipedia.org/wiki/Yaku_we_jap\%C5\%8D\%C5\%84skiym_mahjongu> 15.06.2014). 
Kolejna notka w miarę poprawna stylistycznie i składniowo, trudniej zaakceptować jej tekst:

Masa (uoznoczana buchsztabům $m$ ) - wjelgość fizyczno określajůnco bezwuodność a uoddźauwańa grawitacyjne. Idźe pedźeć aże masa je to ilość materji a ynergije we ćele. Jydnostka masy we Ůkuodźe SI to kilogram $(\mathrm{kg})$. Wartość masy idźe wyrachować podug wzora:

$$
\mathrm{m}=\frac{\mathrm{F}}{\mathrm{a}}(<\mathrm{http}: / / \text { szl.wikipedia.org/wiki/Masa }>) .
$$

Śląskie teksty nie posługują się w zasadzie ani imiesłowami przymiotnikowymi czynnymi, ani anaforycznym to w miejscu orzeczenia. Zatem przytoczone hasło (tym razem zresztą to inny typ pisowni, mający niewiele wspólnego z ustaleniami językoznawczymi) jest próbą zapisu ześląszczonego (w zasadzie wyłącznie w warstwie fonetycznej i częściowo fleksyjnej) tekstu naukowego (popularnonaukowego) ogólnopolskiego.

Takiego efektu usilnie starały się unikać autorki śląskich wersji historycznych notek (biogramów, relacji o faktach historycznych Śląska) dla wspomnianych muzeów: magistrantki, doktorantki i młode panie doktor z Uniwersytetu Śląskiego i Uniwersytetu Jagiellońskiego, pracujące pod moją opieką. Czy efekt można uznać za zadowalający? Myślę, że w dużej mierze tak. Po pierwsze, dzięki temu, że tekstów tych odwiedzający będą słuchać, a nie czytać je i zastanawiać się: „co autor miał na myśli”, stosując taką a nie inną literkę lub połączenie liter. Po drugie, do odczytywania tekstów oba muzea dobierają aktorów, którzy faktycznie mówią po śląsku. Po trzecie jednak, aby zaakceptować efekt tych działań, słuchający powinni przyjąć następujące założenie: chodziło o oddanie pewnej specyfiki mowy śląskiej, uczynienie tekstów zrozumiałymi także dla osób niemówiących po śląsku. Śląska leksyka jest zatem dozowana tak, by jej użycie nie czyniło tekstu niejasnym, znaczenie można wykoncypować z kontekstu (pomaga w tym polski tekst pisany). Po czwarte wreszcie, akceptacja pomysłu jest możliwa przy uznaniu, że teksty te są stylizacją. To wydaje się kluczowe dla wszelkich współczesnych prób wprowadzania śląszczyzny na salony, na deski teatru, karty literatury, do publicystyki itp. Śląszczyznę w wersji podstawowej należałoby pozostawić do obsługi codzienności, a do rozważań niecodziennych, mówienia/pisania o sprawach ducha, stosować stylizację o różnym natężeniu. 
Świadoma stylizacja, oparta na trafnym wyborze, daje o wiele lepsze rezultaty ${ }^{3}$. Oczywiście, można się narazić na różnorakie zarzuty, szczególnie jeśli temat tekstu wzbudza w takiej formie kontrowersje. Niezbyt udanym z punktu widzenia sporej części czytelników przykładem była książka Marka Szołtyska Biblia Ślazoka, jedna z serii jego publikacji (inne to: $\dot{Z} y$ wot Ślązoka poczciwego, Dzieje Śląska, Polski, Europy, Śląskie podróże, Ślazoczki piykne są, Ślązoki nie gęsi - ostatnia zawiera „najpiękniejsze fragmenty literatury światowej «przełonaczone» na śląską gwarę"). Książka Ślązoki nie gęsi nie wzbudziła w zasadzie ogólnej dyskusji, choć znalazły się tam tłumaczenia takich dzieł, jak Iliada Homera, Romeo i Julia Szekspira, Quo vadis Henryka Sienkiewicza, Ania z Zielonego Wzgórza Lucy Maud Montgomery i wiele innych, natomiast Biblia Ślązoka spotkała się ze zdecydowanym oporem - przy czym spór odżywał co pewien czas przez kilka lat, doczekał się nawet komentarza Rady Języka Polskiego:

Biblia Ślązoka to raczej „historie biblijne”, „przetłumaczone” (strawestowane) na dialekt śląski, połączone z eksplikacją poglądów autora na historię i współczesność Górnego Śląska. Razi tam zwłaszcza niezgodność z treścią Pisma Świętego, nieuzasadniona poufałość wyrażana zdrabnianiem imion i teologiczna beztroska „tłumacza”. Na przykład: Ponboczek to zarówno Bóg Ojciec, jak i Jezus: „Ponboczek kozoł ci pedzieć, że poczniesz i urodzisz synka (...) o kerym bydom godać, że je Ponboczkowym Synkiym” (zwiastowanie, por. Łk 1,31-32, s. 46); „Ponboczek uros na fajnego karlusa [to tekst niebiblijny]. Ale w jedna noc zaś przyśnioł sie Zefkowi anioł..." (ucieczka do Egiptu, cf. Mt 2,13) (<http://www.rjp.pan.pl/index.php?option=com_content\&ta$\mathrm{sk}=$ view\&id=154\&Itemid=63>, 15.06.2014).

Jak dowodzą sami autorzy opinii, członkowie Zespołu Języka Religijnego Rady Języka Polskiego, książka Szołtyska zawiera trawestacje, „historie biblijne” - proponowałabym je nawet nazwać współczesnymi apokryfami - a nie tłumaczenia Biblii. „Teologiczną beztroskę” tłumacza należałoby więc uznać za celowy zabieg stylizacyjny - Szołtysek stara się opowiedzieć, streścić, omówić pewne fragmenty Biblii tak, jakby ojciec, starzik, opowiadał je swoim dzieciom czy wnukom: prosto, jasno, zrozumiale, ,autentycznie”. Stąd owo zdrabnianie, bo - jak już kilkakrotnie o tym mówiłam czy pisałam - Ślązacy się w swej mowie specyficznie

${ }^{3}$ Warto wspomnieć i o innych publikacjach nieomawianych w tekście: Piąta strona świata Kazimierza Kutza, Radaś pochylono Bolesława Paździora (swego czasu promowana przez K. Kutza), tetralogia Duchy wojny Alojzego Lyski i inne. 
z Panem Bogiem kamraciyli. W tym zdrabnianiu nie ma lekceważenia, jest szacunek, ale i potrzeba bliskości - więc Maryjka, Pónbóczek, Zefek/Zeflik, Jezusik/Jezusiczek są nazwami, bez których Ślązak (przynajmniej ten z centralnej części Górnego Śląska) nie byłby w stanie wyrazić właściwie swojej religijności i pobożności. Wynika to może także z odwróconej proporcji - etnolekt śląski uważany jest za taki, który bazuje na zgrubieniach, deminutywami posługuje się nadzwyczaj rzadko. Wiele w śląszczyźnie sufiksów zgrubiających (-ok, -ol, -us), zdrabniających jest mało i rzadko są używane (cf. Tambor 2012). Mowa śląska jest z tego powodu odbierana przez osoby niemówiące po śląsku jako gruba, niska, ostra. Na tym tle owe zdrobnienia wyróżniają się jako nazwy specjalne, charakterystyczne, odmiennie postrzegane. Zresztą o specjalnym - nadzwyczaj pozytywnym - stosunku do religijnego składnika tradycji świadczy specyficzny właśnie dla Śląska obraz świąt Bożego Narodzenia. W całej Polsce prezenty pod choinką kładą Święty Mikołaj, Śnieżynka, Aniołek, Gwiazdor. Na Górnym Śląsku przynosi je Dzieciątko, czyli mały Jezus. Nadaje to świętom Bożego Narodzenia ich właściwy wymiar, wyrażony w nazwie - nowo narodzony Jezus obdarza dzieci (dziś już nie tylko, ale to rozważania na inną okazję) w rocznicę swego narodzenia. Słowo „dzieciątko” wpisuje się w serię szczególnych zdrobnień osób boskich, czy szerzej biblijnych, używanych na środkowym Górnym Śląsku; używanych z szacunkiem - nigdy się nie spotkałam z innym ich zastosowaniem. W Szołtyskowej trawestacji i inne elementy leksykalne budziły zastrzeżenia, np. frelka czy anioł Gabriel, który do Marii przifurgnąt. W opinii RJP słowo frelka uznane zostało za frywolne (,czy śląskie trochę lekceważące frelka 'dziewczyna' w odniesieniu do Maryi” cyt. jw.). W kontekście, w jakim zostało użyte, nie jest ono jednak frywolne ani tym bardziej lekceważące: „Jednego dnia do miasta Nazaryt, przifurgnął z nieba anioł Gabriel. Wloz do chałpy, kaj miyszkała tako jedna piykno a pobożno frelka Maryjka" (Szołtysek 2000: 46). Wyraz i jego kontekstowe znaczenia można porównać do ogólnopolskiego „panienka”: może mieć znaczenie bardzo poważne, wysokie, religijne (,przenajświętsza panienka”), może zostać użyte w znaczeniu nawet wulgarnym. Słowo frelka nie nabiera zresztą tego wulgarnego odcienia nawet kontekstowo. Co się tyczy furganio - po śląsku furgo wszystko, co ma skrzydła i nimi porusza: ptak, ważka, mucha, niekoniecznie zaś samolot, który raczej loto, jako że jego skrzydła są nieruchome. Anioł, który 
w stereotypowym ludzkim wyobrażeniu (na wszystkich świętych obrazkach, które w moim dzieciństwie wisiały w śląskich domach nad łóżkami) miał skrzydła złożone (zbudowane) z ptasich piór, poruszał nimi, by się przemieszczać w przestworzach. Czy w tym przypadku należy zastosować „neutralniejsze” dla niektórych, bo bliższe ogólnopolskiemu lotać - to kwestia do rozważań dla Rady Języka Śląskiego, jeśli taka kiedykolwiek powstanie (na wzór Rady Języka Kaszubskiego) i zajmie się różnymi odmianami etnolektu śląskiego. Szołtysek, pisząc swoje pierwsze książki popularne po śląsku, nie dokonywał pod tym względem w pełni świadomych wyborów, w warstwie stylistycznej nie widać różnicy między opowieścią biblijną, fragmentem Iliady czy rubasznym opowiadaniem o oblyckach na cycki (Szołtysek 2005: 30), warto jednak traktować te publikacje jako wstęp do dalszych działań, bo - jak pisze Tomasz Wicherkiewicz - to właśnie ,tradycja literacka, zwłaszcza in statu (re)nascendi, do tej pory pełni istotną rolę w podnoszeniu i konsolidowaniu świadomości językowych wspólnot kolateralnych" (Wicherkiewicz 2014: 16). Owa tradycja ma znaczenie także w momencie powstawania, jeszcze nie do końca wykształcona i usankcjonowana, gdyż przytaczany przez Wicherkiewicza Anthony Smith w artykule z 1989 roku, zatytułowanym The origins of nations, ,jako jedną z cech powstałych w okresie przednowoczesnym «jąder etnicznych» wymienia świadomość granic (między)językowych i wspólnego rodzimego języka lokalnego o rodzącej się tradycji literackiej” (Wicherkiewicz 2014: 16 [podkr. J.T.]).

Języki regionalne, kolateralne, wymienione wcześniej (kaszubski, łemkowski) wypracowywały tradycję literacką przez kilkadziesiąt, nawet sto kilkadziesiąt lat. Górny Śląsk, z różnych względów historycznych i politycznych ${ }^{4}$, nie miał jej do ostatniego dziesięciolecia XX wieku (mówimy oczywiście o literaturze po śląsku, bo spory o to, co znaczy tzw. literatura

\footnotetext{
${ }^{4}$ Można tu choćby przytoczyć opinię M. Siuciak na temat sytuacji z końca XIX wieku, czyli okresu rodzenia się literatury kaszubskiej: „Programowe unikanie zarówno wpływów dialektu śląskiego, jak i wszelkich wyrazistych elementów gwarowych wiązało się z sytuacją polityczną i narodową na Śląsku w XIX wieku. W związku z atakami administracji pruskiej, której koronnym argumentem propagandowym przeciwko polskości Ślązaków był fakt, że nie mówili oni polszczyzną literacką, ale gwarą zawierającą też elementy języka niemieckiego, nadrzędnym celem pisarzy tworzących w okresie wzmożonej akcji germanizacyjnej stało się udowodnienie zaborcy, że Ślązacy potrafią mówić polszczyzną nieskażoną wpływami dialektu i mogą być zrozumiani przez wszystkich Polaków” (Siuciak 1998: 25-26).
} 
śląska, także nie przyniosły jednoznacznych rozstrzygnięć). Dyskusję fachowców na ten temat wywołały np. dwa kolejne numery pisma „Fabryka Silesia" z 2012 roku, ze znamiennymi tytułami tekstów: Czy istnieje literatura śląska J. Lyszczyny ( $\mathrm{nr} 1)$ i tegoż Literatura (nr 2), Literatura ślaska nie istnieje S. Twardocha ( $\mathrm{nr} 1)$ czy Czterdziestu wybiera kanon J.F. Lewandowskiego (nr 1).

Tradycja literatury pisanej po śląsku (a przynajmniej Górnego Śląska środkowego) zaczyna się dopiero w ostatnim ćwierćwieczus. To rozwój intensywny. Można twierdzić, że śląszczyzna pod tym względem ma szansę dogonić kaszubszczyznę czy łemkowszczyznę w czasie zdecydowanie krótszym, niż budowali swoją tradycję literacką użytkownicy tamtych etnolektów. Możliwość tego przyspieszenia stwarza choćby bardzo łatwy obecnie dostęp do druku. Sporo jest w tej dziedzinie amatorszczyzny, sporo utworów, które są absolutnym kiczem i nie przetrwają nawet kilku dni, coraz więcej jednak jest prawdziwej literatury. Można do niej zaliczyć śląską przeróbkę sceniczną Cholonka Janoscha (wystawianą przez katowicki Teatr Korez), pisany po śląsku i „myślany” po śląsku Polterabend Stanisława Mutza (wystawiany przez Teatr Śląski im. S. Wyspiańskiego), Mitość w Königshütte Ingmara Villqista czy dziesiątki jednoaktówek nadsyłanych na konkurs, z których wybrane są publikowane w pokonkursowych tomach Bysuch z Reichu. Jednoaktówki po ślasku (2013) i Rajzyntasza. Jednoaktówki po ślasku (2013). O konkursie i jego idei pisze I. Villqist:

Bo to język/gwara/dialekt/etnodialekt, jak zwał, tak zwał, którym Ślązacy posługują się od stuleci i który tworzy przestrzeń ich wzajemnej komunikacji emocjonalnej. (...) poziom tych prac, sposób formułowania dialogów, opowiadania przez nie historii, budowania postaci, ich przeszłości, dzisiejszości świadczył tak o predyspozycjach do posługiwania się dialogami (w kilku przypadkach odkryłem prawdziwe talenty), jak i umiejętności wykorzystania języka śląskiego do konstruowania bogatej przestrzeni emocjonalnej w tworzonych historiach właściwej dla ,prawdziwego języka” takiego czy innego. Więc jak to jest z tym śląskim? (...) Nic tak nie zweryfikuje takich pytań, jak próba literatury (Rajzyntasza 2013: 10).

Szkoda, że do czasu wydania jednoaktówek nie udało się środowiskom związanym z życiem literackim na Śląsku dojść do porozumienia

${ }^{5}$ Można i wcześniej wskazywać różne zbiory godek, bojek, berów, wiców - jednak były to fakty jednostkowe. 
w sprawie pisowni, byłby to bowiem kolejny stopień w tworzeniu tradycji literackiej. O braku decyzji co do pisowni świadczą bowiem nie tylko same teksty, ale też leksemy śląskie używane w tytułach antologii przez redakcje. W pierwszym tomie bysuch - pół śląska (e pochylone w postaci $y$ ), pół graficznie niemiecka (środkowe $s$, wymawiane jako [z]), w drugim w pełni zeswojszczony zapis rajzyntasza.

W tym miejscu warto zwrócić uwagę na dwie publikacje Zbigniewa Kadłubka Listy z Rzymu (2008) i Prōmytojs przibity (2013). Pierwszy zbiór stylizowanych esejów, felietonów, listów literackich, pisany był w półfonetycznej grafii opartej na ortografii ogólnopolskiej, drugi wykorzystywał już ustalenia tzw. zespołu ślabikorzowego. Sposób przekazu Ajschylosowych myśli jest najwyższej próby. To stylizacja, trudno nazwać ją pełnym, dokładnym tłumaczeniem, jednak jest to stylizacja w pełni świadoma, zawierająca przekaz śląskiego myślenia, w którym zawarta jest nadal w pełni myśl Ajschylosa. Aleksandra Kunce we wstępie pisze:

Cenię ten projekt translacyjny również z powodów pragmatycznych. Wpisuje się w wypracowanie marki śląskiej. Wyrazistość w tej przestrzeni pewnie będzie postępować, o ile nie zetknie się z indolencją czy wrogością władzy. Sukces jest tu uzależniony od jednego: wprowadzenia zasady „nie przeszkadzać”. Nie jest to tylko powtarzany bezrefleksyjny ruch produkcji prezentów, gadżetów, książek o Śląsku i pisanych po śląsku, czasopism, które troszczą się o Śląsk. To coś więcej. To umocnienie pewności siebie i czytelnej komunikacji tego, kim jesteśmy. Zakorzenienie, nowocześnie przetworzone, jest wielką szansą dla Śląska. Marką śląską jest właśnie idea zakorzenienia. (...) Myślę, że Zbyszek Kadłubek wzmocnił swe myślenie o Górnym Śląsku w otoczeniu myśli Ajschylosa. (...) Markę śląską trzeba nieustannie wzmacniać, a odważna translacja jest takim czynem (Kunce, cyt. za Ajschylos 2013: 18).

W Listach z Rzymu Kadłubek zadaje sobie pytanie: „Skond jo byda, jak już niy bydzie Ślonska?” (Kadłubek 2008: 30). Jestem przekonana, że coraz liczniejsze śląskie inicjatywy pisarskie na długo odsuną taką możliwość. Są one dowodem na wytwarzanie się tradycji literackiej, pokazują, że argumenty przeciwników idei śląskiego języka literackiego jako języka sztucznie stworzonego są bezpodstawne. Tworzy się on dosłownie na naszych oczach, coraz bliżej więc chyba do bezkonfliktowego usankcjonowania go jako rezerwuaru ,elementów pozwalających wyartykułować odrębność kulturową albo nawet cywilizacyjną danego społeczeństwa" (Lubaś 2009: 97). 


\section{Literatura}

Ajschylos, 2013, Prōmytojs przibity, przeł. Z. Kadłubek, Kotórz Mały.

Bysuch. Jednoaktówki po śląsku, 2013, Katowice.

Czajkowski A. (red.), 2006, Wielki słownik śląsko-niemiecko-angielski, Katowice.

Czajkowscy A., Kulkowska D., Klukowski A. (red.), 1996, Słownik gwary śląskiej, Katowice.

Cząstka-Szymon B., Ludwig J., Synowiec H., 1999, Mały słownik gwary Górnego Śląska, cz. 1, Katowice.

Dyrda D., 2009, Rýchtig gryfno godka (porěncznik ślůnskij godki), Tychy.

„Fabryka Silesia”, 2012, nr 1, 2.

Fontański H., 2014, Studia nad sktadnia łemkowska, Katowice.

Furgalińska J., 2010, Ślónsko godka. Ilustrowany słownik dla Hanysów i Goroli, Warszawa.

Kadłubek Z., 2008, Listy z Rzymu, Katowice.

Kallus B., 2007, Słownik gôrnoślônskij godki, Katowice.

Kortko D., Jodliński L. (red.), 2010, Najpiękniejsze śląskie słowa. Antologia, Katowice.

Lubaś W., 1998, Czy powstanie śląski język literacki?, „Język Polski” nr 1-2, s. 49-56.

Lubaś W., 2009, Polityka językowa, Opole.

Lubaś W., 2013, Studia socjolingwistyczne, Opole.

Majewicz A.F., 1989, Języki świata i ich klasyfikowanie, Warszawa.

Podgórska B., Podgórski A., 2008, Słownik gwar śląkich. Godómy po naszymu, czyli po śląsku, Katowice.

Przymuszała L., 2013, Słownik frazeologizmów i typowych połaczeń wyrazowych w gwarach śląskich, Opole.

Rajzyntasza. Jednoaktówki po śląsku, 2013, Katowice.

Roczniok A., 2007, Zbornik polsko-ślionski poduk normy ISO 639-3 szl, Zabrze.

Rospond S., Sochacka S. (red.), 1970, Stownik etymologiczny nazw geograficznych Śląska, Opole.

Siuciak M., 1998, Język śląskich utworów scenicznych z lat 1864-1922, Katowice.

Szołtysek M., 1999, Ilustrowany słownik gwary śląskiej, Rybnik.

Szołtysek M., 2000, Biblia Ślazoka, Rybnik.

Szołtysek M., 2005, Ślązoczki piykne są, Rybnik.

Tambor J., 2012, Językowe wyróżniki emocjonalności w etnolekcie śląskim, „Rozprawy Komisji Językowej” Łódzkiego Towarzystwa Naukowego, t. 58, Łódź, s. 343-352.

Wicherkiewicz T., 2014, Regionalne języki kolateralne Europy - porównawcze studia przypadku z polityki językowej, Poznań.

Wyderka B., (red.), 2000 i n., Słownik gwar śląskich, t. 1 i n., Opole.

Źródła internetowe

$<$ http://szl.wikipedia.org/wiki/\%C5\%9Al\%C5\%AFnsko_Wikipedyjo>

$<$ http://www.rjp.pan.pl/index.php?option=com_content\&task=view\&id=154\&Ite$\operatorname{mid}=63>$ 